\title{
Design Calculation of Parabolic Trough Solar Thermal System and Three-phase Turbo Alternator
}

\author{
Theingi Htun*, Myo Thet Tun** \\ * Department of Electrical Power Engineering, Mandalay Technology University \\ Mandalay, Myanmar
}

\begin{abstract}
Article Info
Article history:

Received Apr 14, 2015

Revised Jul 10, 2015

Accepted Jul 22, 2015

\section{Keyword:}

Exit temperature

Parabolic trough collectors

Synchronous generator

Thermal storage

Useful heat gain

ABSTRACT

Solar energy can be converted into thermal energy with the help of solar collectors. Electricity can be produced directly from solar energy using photovoltaic devices or indirectly from steam generators using solar thermal collectors to heat a working fluid. This research is using the conversion of solar energy into electricity in a closed cycle driven by natural convection. It would mean that electricity is cheaper than from any other renewable technology and cheaper than from fossil fuels. This paper describes converting thermal energy collected by solar collector to electricity by using turbine. Anywhere in Myanmar will cheaply use electricity by using solar turbine generator. Remote areas will improve more and more when getting the efficient electricity. The design calculation and performance predication of 1 MVA turbo-alternator/generator are also mentioned. Design calculation of absorbed flux, useful heat gain and exit temperature is described. And then development of two-tank thermal storage system that uses molten salt as the heat transfer fluid is described.
\end{abstract}

Copyright (C) 2015 Institute of Advanced Engineering and Science. All rights reserved.

\section{Corresponding Author:}

Theingi Htun

Department of Electrical Power Engineering, Mandalay Technology University

Mandalay, Myanmar

Email: aprilladydream@gmail.com

\section{INTRODUCTION}

There are three types of solar thermal generation in general. They are parabolic dish, parabolic trough, and central receiver or power tower system. The cornerstone of solar parabolic trough plant is the solar field. The solar field consists of parabolic trough collectors and piping. Parabolic trough collectors can be divided into two subsystems: the solar collection assembly (SCA) and the heat collection element (HCE). The SCA also includes the single-axis tracking equipment and support structure for the HCEs. During operation, solar radiation is reflected from the SCA onto the parabolic trough's focal line, where the HCE resides [1-2]. 


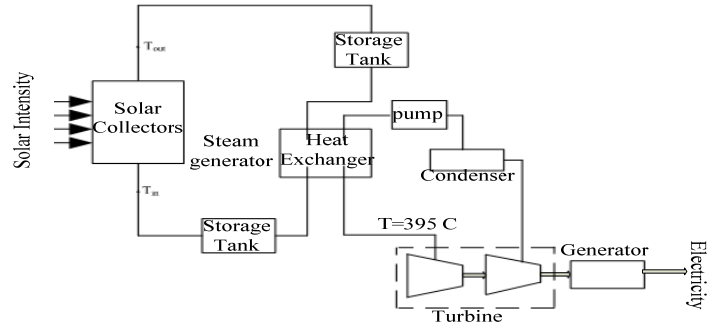

Figure 1. Schematic Diagram of Parabolic Trough Solar Thermal Electrification

The steam is used to describe the heat exchangers that heat the working fluid, highly pressurized water, from a compressed liquid state into a superheated vapor statein Figure 1. The preheated warms the working fluid from compressed liquid to saturated liquid. Due to the latent heat of evaporation the steam generator is the most energy intensive heat exchanger. This paper describes converting thermal energy collected by solar collector to electricity by using turbine. Anywhere in Myanmar will cheaply use electricity by using solar turbine generator. Remote areas will improve more and more when getting the efficient electricity [3].

\section{DESIGN CALCULATION}

\section{Geometry of Wyargyi Village}

Wyargyi village is situated between North Latitude $20^{\circ} 25^{\prime}$ and East Longitude $96^{\circ} 09^{\prime}$. The elevation above sea level is $74.676 \times 10^{-3} \mathrm{~m}$ and situated Mandalay Region within tropical zone. The local standard time of meridian is $97^{\circ} 30^{\prime} \mathrm{E}$. The temperatures, sunshine hour, and total solar radiation of Wyargyi village for the year 2014 are maintained in Table 1 and Table 2. The data are obtained from Department of Meterology and Hydrology (Myanmar - Wyargyi village). Figure 2 shows variation of solar intensity and time. [4].

Table 1. Temperatures ( $\left.{ }^{\circ} \mathrm{C}\right)$ and Sunshine Hour of Wyargyi Village

\begin{tabular}{ccc}
\hline Month & Temperature ${ }^{\circ} \mathrm{C}$ & Sunshine hour \\
\hline January & 31.7 & 7.8 \\
February & 36.3 & 9.5 \\
March & 38.5 & 9.2 \\
April & 40.1 & 10.8 \\
May & 35.6 & 11.2 \\
June & 34.0 & 9.3 \\
July & 33.0 & 9.0 \\
August & 31.4 & 9.2 \\
September & 32.2 & 9.0 \\
October & 31.4 & 8.5 \\
November & 31.3 & 7.4 \\
December & 27.8 & 6.8 \\
\hline
\end{tabular}

Table 2. The Total Radiation for Horizontal Surface

\begin{tabular}{ccr}
\hline Time $(\mathrm{hr})$ & Temperature ${ }^{\circ} \mathrm{C}$ & Sunshine hour \\
\hline $6-7 \mathrm{am}$ & 0.29707 & $1.11567 \times 10^{-5}$ \\
$7-8 \mathrm{am}$ & 0.92317 & 0.41511 \\
$8-9 \mathrm{am}$ & 1.49227 & 0.995211 \\
$9-10 \mathrm{am}$ & 1.5875 & 1.53001 \\
$11-12 \mathrm{am}$ & 1.99767 & 1.9236 \\
$12-1 \mathrm{pm}$ & 2.21167 & 2.1305 \\
$1-2 \mathrm{pm}$ & 2.21167 & 2.1305 \\
$2-3 \mathrm{pm}$ & 1.99767 & 1.9236 \\
$3-4 \mathrm{pm}$ & 1.5875 & 1.53001 \\
$4-5 \mathrm{pm}$ & 1.49227 & 0.995211 \\
$5-6 \mathrm{pm}$ & 0.92317 & 0.41511 \\
$6-7 \mathrm{pm}$ & 0.29707 & $1.11567 \times 10^{-5}$ \\
Total $\left(\mathrm{MJ} / \mathrm{m}^{2}\right)$ & 17.0187 & 13.9888 \\
$\left(\mathrm{~W} / \mathrm{m}^{2}\right)$ & 4727.4166 & 3885.8011 \\
\hline
\end{tabular}




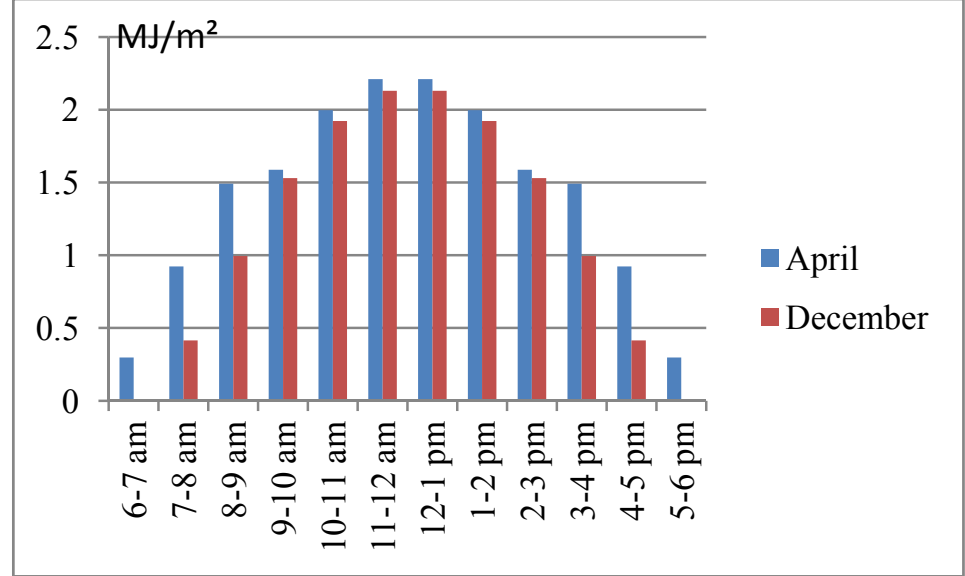

Figure 2. Variation of Solar Intensity and Time

\section{DESIGN CALCULATION DATA OF PARABOLIC TROUGH}

Date April $15=40.1{ }^{\circ} \mathrm{C}$ and December $15=27.8^{\circ} \mathrm{C}$

The data in table 2 are used and calculated with the following equations for design calculation of parabolic trough. Design calculation results show in table 3.

\begin{tabular}{cc}
\hline Specular reflectivity of the concentrator surface, $\rho$ & 0.94 \\
\hline Glass cover transmittivity for solar radiation, $\tau$ & 0.88 \\
Absorber tube emissivity /absorptivity, $\alpha$ & 0.96 \\
Intercept factor, $\gamma$ z & 0.95 \\
Mass flow rate of water, m & $0.09 \mathrm{~kg} / \mathrm{s}$ \\
Inlet temperature & $60^{\circ} \mathrm{C}$ \\
\hline
\end{tabular}

The equations of absorbed flux, useful heat gain, and exit temperature

$$
\begin{aligned}
& S=I_{b} r_{b} \rho \gamma(\tau \alpha)_{b}+I_{b} r_{b}(\tau \alpha)_{b}\left(\frac{D_{o}}{W-D_{o}}\right) \\
& q_{u}=F_{R}\left(W-d_{c o}\right) L\left[S-\frac{U_{L}}{c}\left(T_{f i}-T_{a}\right)\right] \\
& m c_{p} \Delta T=q
\end{aligned}
$$

\begin{tabular}{|c|c|c|c|c|c|c|}
\hline \multirow[t]{2}{*}{ Time (hr) } & \multicolumn{2}{|c|}{$\mathrm{S}\left(\mathrm{W} / \mathrm{m}^{2}\right)$} & \multicolumn{2}{|c|}{$\mathrm{Q}(\mathrm{kW})$} & \multicolumn{2}{|c|}{$\mathrm{T}_{\mathrm{fo}}\left({ }^{\circ} \mathrm{C}\right)$} \\
\hline & April & December & April & December & April & December \\
\hline 6-7 am & 64.2859 & 2.4142 & 89.2860 & -72.7649 & 60.1603 & 59.8694 \\
\hline $7-8 \mathrm{am}$ & 199.7741 & 89.8298 & 378.8027 & 114.0283 & 60.6799 & 60.2047 \\
\hline $8-9$ am & 322.9273 & 215.3638 & 641.9615 & 382.2744 & 61.1522 & 60.6861 \\
\hline $9-10 \mathrm{am}$ & 343.5351 & 331.0943 & 685.9971 & 629.5721 & 61.2312 & 61.1299 \\
\hline $10-11 \mathrm{am}$ & 432.2959 & 416.2672 & 875.6648 & 811.5730 & 61.5716 & 61.4566 \\
\hline $11-12 \mathrm{am}$ & 478.6056 & 461.0404 & 974.6213 & 907.2462 & 61.7492 & 61.6283 \\
\hline $12-1 \mathrm{pm}$ & 478.6056 & 461.0404 & 974.6213 & 907.2462 & 61.7492 & 61.6283 \\
\hline $1-2 \mathrm{pm}$ & 432.2959 & 416.2672 & 875.6648 & 811.5730 & 61.5716 & 61.4566 \\
\hline $2-3 \mathrm{pm}$ & 343.5351 & 331.0943 & 685.9971 & 629.5721 & 61.2312 & 61.1299 \\
\hline $3-4 \mathrm{pm}$ & 322.9273 & 215.3638 & 641.9615 & 382.2744 & 61.1522 & 60.6861 \\
\hline $4-5 \mathrm{pm}$ & 199.7741 & 89.8298 & 378.8027 & 114.0283 & 60.6799 & 60.2847 \\
\hline $5-6 \mathrm{pm}$ & 64.7741 & 2.4142 & 89.2860 & -72.7649 & 60.1603 & 59.8694 \\
\hline Total & 3682.8478 & 3032.0194 & 7292.6668 & 5543.8582 & 733.0888 & 730.03 \\
\hline
\end{tabular}

Table 3. Results of Absorbed Flux, Useful Heat Gain and Exit Temprature in April and December 


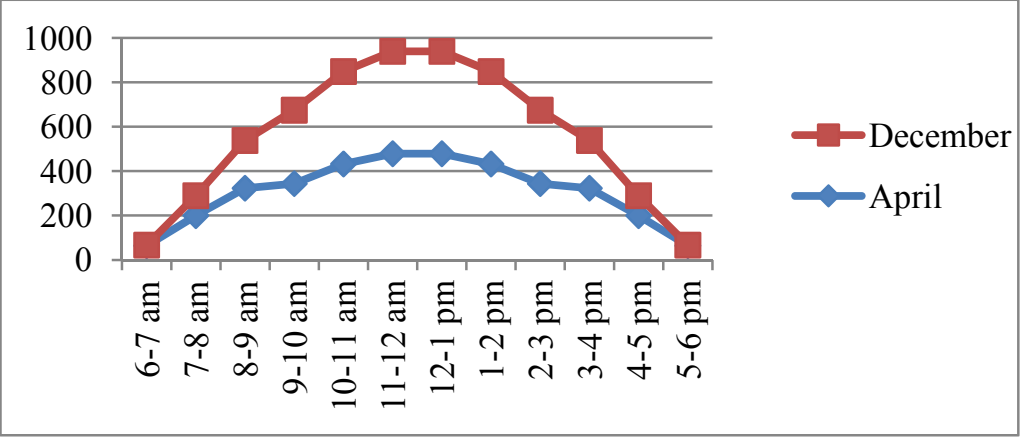

Figure 3. Results of absorbed flux, $\mathrm{S}$ in April and December

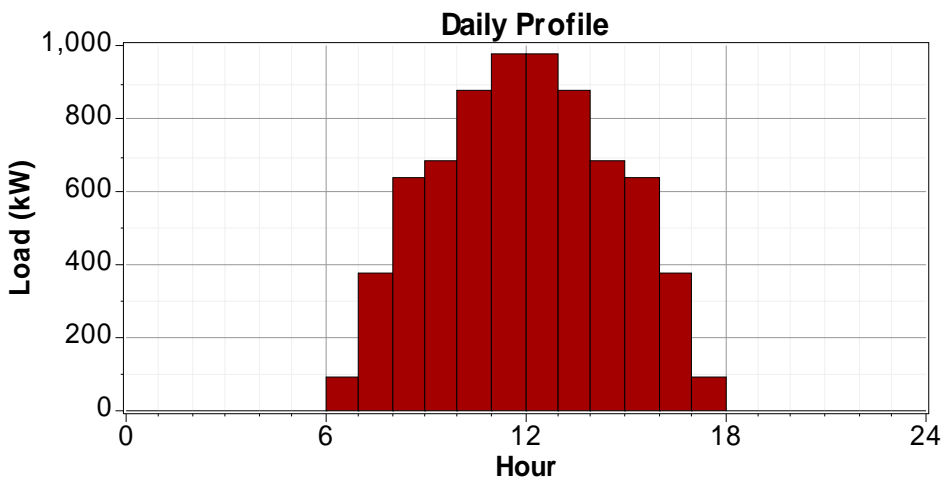

Figure 4. Simulation results of daily load profile in April

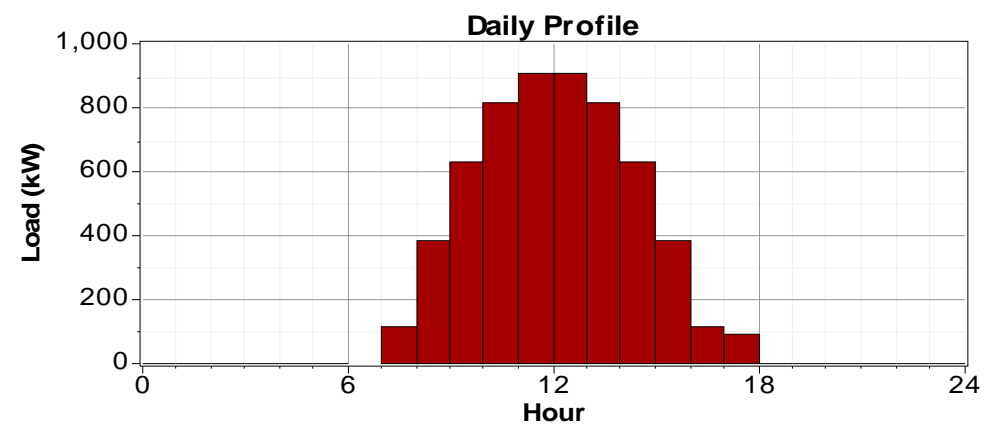

Figure 5. Simulation results of the useful heat gain

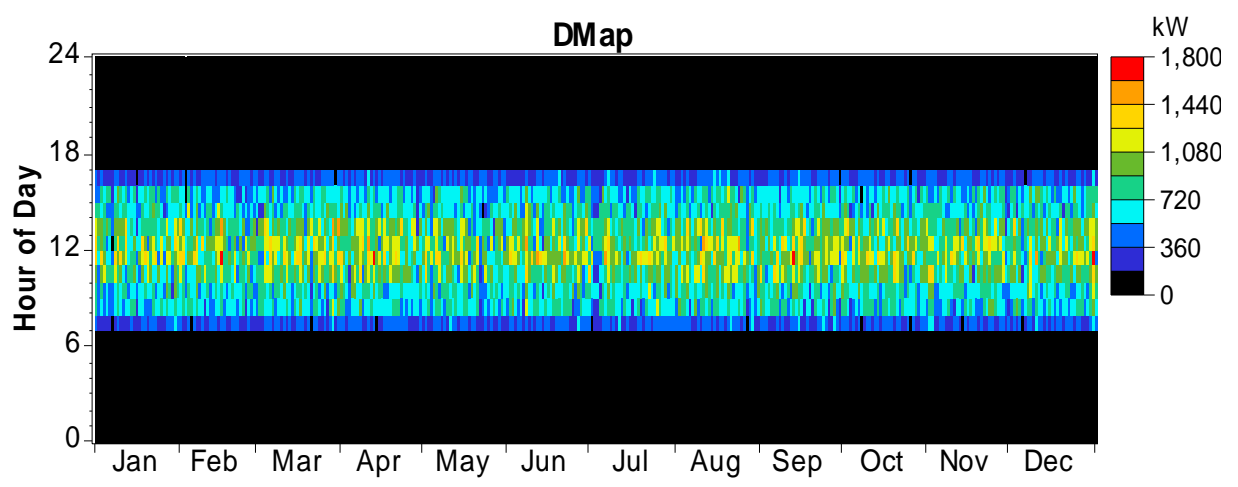

Figure 6. Simulation results of useful heat gain 


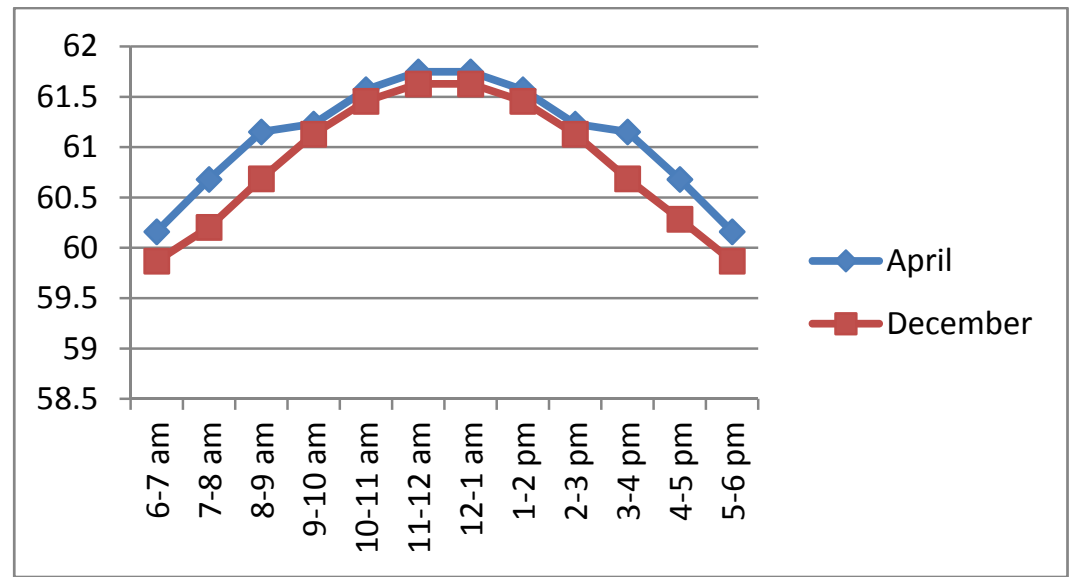

Figure 7. Results of exit temperature in April and December

Figure 3 shows resultsof absorbed flux, Sin April and December in time zones. The absorbed flux, S is the most at 11-12 am and 12-1 pm in April. In December, the absorbed flux is the most at 11-12 am and 12-1 pm. Figure 4 and figure 5 show simulation results of daily load profile in April and December with twelve time zones. The most useful heat gain is $974.6213 \mathrm{~kW}$ and the least useful heat gain is $89.2860 \mathrm{~kW}$ in April. The most useful heat gain is $907.2462 \mathrm{~kW}$ in April and the least useful heat gain is $-72.7649 \mathrm{~kW}$ in Decmber. Figure 6 shows simulation results of useful heat gain in twelve time zones. Figure 7 shows results of exit temperaturein April and December [5].

\section{TWO-TANKS OF THERMAL STORAGE}

In The two-tank thermal storage can be integrated into a parabolic trough plant. The basic operating strategy is to charge thermal storage when the HTF flow rate exceeds the design flow rate for steam generation. During charging, molten salt leaves the cold tank extracts heat from the HTF, and then enters the hot tank. The temperature of the HTF heated by discharging salt will be lower than the HTF temperature directly from the solar field because the heat has passed through two heat exchangers and an associated heat loss inside the hot tank. This decrease in temperature will result in a decrease in power generation. The hot and cold storage tanks as shown in Figure 8 were identical with only the temperature of salt varying. For a desired increase in thermal storage, the tank volume and area must increase. The surface area is 39 meter and tall tank is 19 meter. The height was approximated to be 11.7 meters. [6].

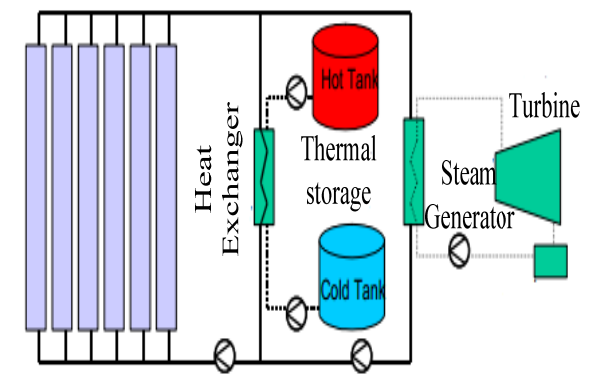

Collector Field

Figure 8. Schematic of a Two-tank Thermal Storage System 
5. DESIGN CALCULATION OF THREE-PHASE 1 MVA AC SYNCHRONOUS GENERATOR

\begin{tabular}{cc}
\hline Specification & Three-phase turbo alternator generator \\
\hline Output capacity & $1 \mathrm{MVA}$ \\
Generator output voltage & $11 \mathrm{kV}$ \\
Phase voltage & $6350 \mathrm{~V}$ \\
Power factor & 0.8, lagging \\
Speed & $3000 \mathrm{rpm}$ \\
Frequency & $50 \mathrm{~Hz}$ \\
Number of poles & 2 poles \\
Type of Drive & Steam Turbine \\
\hline
\end{tabular}

Equations of three-phase turbo alternator for parabolic trough solar thermal

$$
\begin{aligned}
& D=\frac{v}{\pi \times n_{s}} \\
& D^{2} L=\frac{Q}{K^{\prime} n_{s}} \\
& \tau_{p}=\frac{\pi D}{p} \\
& E_{p}=4.44 f k_{w} \phi T_{p h} \\
& B_{t}=\frac{\phi}{N_{t} \times b_{t} \times L_{i}} \\
& R_{f}=\frac{\rho L_{m l} T_{f}}{a_{f}} \\
& I_{R}=I_{p h} \times R_{s} \times k_{d a v} \\
& \lambda_{s}=\frac{h_{1}}{3 b_{s}}+\frac{h_{2}}{b_{s}}+\frac{2 h_{3}}{b_{s}+b_{o}}+\frac{h_{4}}{b_{o}} \\
& \phi_{s}=2 \sqrt{2} \mu_{o} I_{p h} L_{s} \lambda_{s} T_{c} \\
& A T_{a}=\frac{1.35 T_{p h} I_{p h} k_{w}}{p} \\
& A T_{f_{o}}=A T_{a} \times S . C . R \\
& h_{f}=\frac{I_{f} T_{f}}{10^{4} \sqrt{d_{f} S_{p} P_{f}}}
\end{aligned}
$$


Table 4. Symbol and Description for Three-phase Turbo Alternator

\begin{tabular}{cc}
\hline Symbol & Speed (rpm) \\
\hline$\tau_{p}$ & Internal diameter of stator \\
$B_{t}$ & Pole pitch \\
$\varphi_{t}$ & Width of tooth at gap surface \\
$N_{t}$ & Pole arc \\
$R_{F}$ & Resistance of stator winding per phase \\
$L_{m l}$ & Mean length of turn \\
$k_{d a v}$ & Average loss factor \\
$\lambda_{s}$ & Specific slot permenance \\
$h_{1}$ & Space coupled by insulated conductor in the slot \\
$h_{2}$ & Space above the conductor and below the wedge \\
$h_{3}$ & Space occupied by wedge \\
$h_{4}$ & Space occupied by wedge \\
$b_{o}$ & Slot opening \\
$\phi_{s}$ & Slot leakage flux \\
$A T_{a}$ & Armature ampere turns per pole \\
$A T_{f o}$ & No load ampere turn per pole \\
$h_{f}$ & Height of field coil \\
$d_{f}$ & Depth of field coil \\
$S_{f}$ & Space factor \\
$P_{f}$ & Permissible loss $/ \mathrm{m}^{2}$ \\
\hline
\end{tabular}

As the rotor slot pitch is $8.14 \mathrm{~cm}$, so the two conductors with $3.8 \mathrm{~mm}$ side can be accommodated in the slot foe 1 MVA, width wise. [7], [8].

As a result, 47 conductors will be arranged in a slot, depth wise for 1 MVA. Insulation provided in the slot must be in a position to withstand.

(i) Great mechanical stresses and

(ii) The factors which are due to expansion of slot contents having different thermal expansion coefficient. Insulation on the field coil is provided as follows:

(i) $0.5 \mathrm{~mm}$ hard mica cell is provided all round field coil

(ii) Over the hard mica cell, a $1.5 \mathrm{~mm}$ flexible mica cell is provided on the field coil.

(iii) Lastly a steel of $0.6 \mathrm{~mm}$ enclose the whole field coil [9], [10].

In addition to the above, various turns slot height is separated from each other by $0.3 \mathrm{~mm}$ pressed mica separators.

Slot width $\quad \mathrm{mm}$

Space occupied by copper conductor, $2 \times 3.8 \quad 7.6$

Mica separator, $1 \times 0.3$

Hard mica cell on the conductor, $3 \times 0$

Flexible mica cell on the conductor, $3 \times 1.5 \quad 4.5$

Steel cell over the conductor, $2 \times 0.6 \quad 1.2$

Mica strip in the slop, $2 \times 0.6$

Slackness $\quad 0.9$

Total slot width $\quad 17.2 \mathrm{~mm}$

$1.72 \mathrm{~cm}$

Slot depth:

Copper conductors, $47 \times 4$

$\mathrm{mm}$

188.0

Mica separators, $(47-1) \times 0.3 \quad 13.8$

Hard mica cell on the conductor, $3 \times 0.5 \quad 1.5$

Flexible mica cell on the conductor, $3 \times 1.5 \quad 4.5$

Steel cell over the conductor, $2 \times 0.6 \quad 1.2$

Mica bottom strip in the slot $\quad 2.0$

Design Calculation of Parabolic Trough Solar Thermal System and Three-phase Turbo ...(Theingi Htun) 
Copper strip under the wedge

Slackness

Total slot depth
25.0

1.9

$237.9 \mathrm{~mm}$

$23.79 \mathrm{~cm}$

Table 5. Results for Three-phase Turbo Alternator generator

\begin{tabular}{cc}
\hline Resistance of the field winding & $2.88 \mathrm{ohm}$ \\
\hline Copper loss in each field coil & $184.32 \mathrm{~W}$ \\
Total losses in all coils & $364.64 \mathrm{~W}$ \\
Brush contact loss with 1 volt, drop at each brush & $16 \mathrm{~W}$ \\
Total field copper losses & $384.64 \mathrm{~W}$ \\
Input to the exciter & $437.09 \mathrm{~W}$ \\
Exciter losses & $54.45 \mathrm{~W}$ \\
Friction and winding losses & $8 \mathrm{~kW}$ \\
Area of the tooth, $\mathrm{A}_{\mathrm{t}}$ & $0.0164 \mathrm{~m}^{2}$ \\
Volume of the tooth & $0.00211 \mathrm{~m}^{3}$ \\
No of teeth & 24 \\
Volume of all teeth & $0.05064 \mathrm{~m}^{3}$ \\
Weight of the teeth & $394.992 \mathrm{~kg}$ \\
Flux density in the teeth & $1.78 \mathrm{Tesla}(\mathrm{assumed})$ \\
Tosses & $28 \mathrm{~W}$ \\
Total losses in the teeth & $11.06 \mathrm{~kW}$ \\
Volional area of the stator core & $0.2902 \mathrm{~m} \mathrm{~m}^{2}$ \\
Weight of the stator core & $1.522 \mathrm{~m}$ \\
Flux density in the tere & $601.19 \mathrm{~kg}$ \\
Toth & $1.2 \mathrm{Tesla}(\mathrm{assumed})$ \\
Total losses in the stator core & $12 \mathrm{~W}$ \\
Total iron losses & $7.224 \mathrm{~kW}$ \\
& $18.284 \mathrm{~kW}$ \\
\hline
\end{tabular}

Efficiency,

Total losses

$\mathrm{kW}$

Total iron losses $\quad 18.28$

Total losses of stator $\quad 2.83$

Total field copper losses $\quad 0.385$

Exciter losses $\quad 0.052$

Friction and winding losses $\quad 8$

$29.55 \mathrm{~kW}$

Otput of the alternator $=1 \times 10^{3} \times 0.8=800 \mathrm{~kW}$

Efficiency $=\frac{800}{800+29.55}=96.4 \%$

\section{CONCLUSION}

Technical evaluation of a Solar Parabolic Trough System was performed in Wyargyi village, Thazi Township in Mandalay Division. From the temperature data of year 2014, the maximum temperature is occurred at April and the minimum temperature is occurred at December. The heat gain from collector to receiver, working fluid heat energy, and the storage system are also concerned with temperature variation. In this paper, development of two-tank storage system that uses molten salt as the heat transfer fluid is described. The detail design calculations of absorbed flux, the useful heat gain, exit temperature, and threephase turbo alternator design are presented and calculated. Simulation results of daily load profile and useful heat gain in April and December in twelve time zones are presented. At present, there is still no practical experience in the operation of this power plant technology in Myanmar. The solar thermal system can reduce carbon emission and cost of transmission losses.

\section{ACKNOWLEDGEMENTS}

The author is deeply grateful to her parents, U Tun Kyi and Daw Ohm Kyin for their supports and encouragement to attain her destination without any trouble and all the persons who share the trouble of the author on any situation in trying this paper. 
Moreover, the author would like to thank sisters. Thanks to all her teachers, friends, and family members, for inspiring and motivating her. The author is deeply grateful to all the persons who helped directly or indirectly towards the accomplishment of this paper.

\section{REFERENCES}

[1] Michael West, Ph.D. June. Solar Energy Basics and More. (1993).

[2] John a. Duffie \& William a. Beckman. Solar Engineering of Thermal.

[3] Bradshaw, R.W., C.E. Tyner, 1988, Chemical and Engineering. Factors Affecting Solar Central Receiver Applications of Ternary Molten Salts, Sandia National Laboratories Report, SAND88-8686.

[4] Anonymous; Renewable Energy World Global Concentrated Solar Power Industry to Reach 25 GW by 2020 http://www.renewable energy world.com/rea/news/aricle/2009/05/global-concent rated solar-power-industry-to reach-25-gw-by-2020 cmpid=WNL-Friday-May 8-2009

[5] Simulation and performance evaluation of parabolic trough solar power system by Angela M. Patnode et al http://www.solar 2006.org/presentations/tureechsessions/t38-A029.pdf..

[6] Herrmann, UIF, et al.2002, "Overview on Thermal Storage Systems, "Flabeg Solar International Gmblt", Workshop on Thermal Storage for Trough Power Systems.

[7] Sawhney, A.K.: A Course in Electrical Machine Design, Dhanpat Rai \& Sons, (1984).

[8] Say, M.G.: Performance and Design of Alternating Current Machines, Pitman and Sons, Ltd., $3^{\text {rd }}$ Edition, University of London, (1976).

[9] Shoichi Oda, S.: Alternating Current Machines, Electrical Engineerg Course, (1959).

[10] Mittle V.N. and Mittnal A. Design of Electrical Machines, Delhi Standard Publisher Distributors, 2000.

\section{BIOGRAPHIES OF AUTHORS}

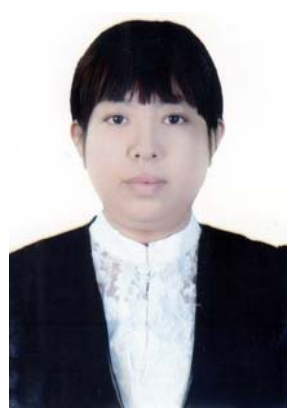

The author's name is Ms. Theingi Htun. She was born on $1^{\text {th }}$ June 1983. She got ME degree in Electrical Power Engineering from Mandalay Technological University, Myanmar. And she is also working as an assistant lecturer at Technological University (Taunggyi). Now, she is attending Ph.D degree in Electrical Power in Mandalay Technological University, Myanmar. She achieved ICSE paper that held in Inyar Lake hotel and International paper from ICTAEECE Conference that held in Bangkok during this year. Her main interest is in Renewable Energy and Generator Design. Her email is aprilladydream@gmail.com.

Dr.Myo Thet Tun, Associate Professor, Department of Electrical Power Engineering, Mandalay Technological University, Myanmar. 